\title{
Kasveissa tuotettu rokote porsaiden vieroitusripuliin
}

\author{
Jussi Joensuu ${ }^{1}$, Mirkka Kotiaho ${ }^{1}$, Hannu Lång ${ }^{2}$, E. Tapio Palva ${ }^{2}$, Teemu H. Teeri ${ }^{1}$, Eric Cox $^{3}$ ja Viola
} Niklander-Teeri ${ }^{1}$

${ }^{1}$ Soveltavan biologian laitos, PL 27,00014 Helsingin yliopisto,jussi.joensuu@helsinki.fi, mirkka.kotiaho@,helsinki.fi,teemu.teeri@helsinki.fi,viola.niklander-teeri@helsinki.fi

${ }^{2}$ Bio- ja ympäristötieteiden laitos, PL 56, 00014 Helsingin yliopisto, hannu.lang@helsinki.fi, tapio.palva@,helsinki.fi

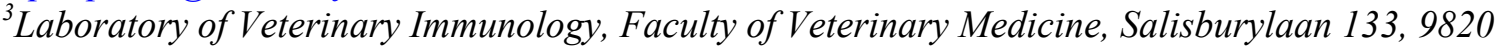

Merelbeke,Universiteit Gent,Belgium, eric.cox@ugent.be

\section{Johdanto}

Porsailla esiintyy yleisesti ripulia vieroitusvaiheessa (3-5 viikon iässä). Vieroituksen aikana ternimaidosta saadut vasta-aineet alkavat vähentyä ja porsaiden oma vasta-aineiden tuotto on vasta alkamassa. Tällöin haitalliset suolistobakteerit pääsevät helposti kolonisoimaan ohutsuolen ja aiheuttamaan ripulin. Yleisimpiä vieroitusripulin aiheuttajia ovat enterotoksiineja tuottavat Escherichia coli (ETEC) kannat.

ETEC kantojen tuottamat enterotoksiinit häiritsevät nesteiden ja elektrolyyttien normaalia imeymistä suolenseinämän läpi ja aiheuttavat ripulin (Bertschinger ja Fairbrother 1999). Avainasemassa taudin puhkeamisessa enterotoksiinien lisäksi on ETEC-bakteerien kyky tarttua suoliston limakalvoepiteeliin (Cowart 1995). ETEC-bakteerit tarttuvat limakalvoepiteelin reseptoreihin pintansa hiusmaisten proteiinirakenteiden avulla. Näitä antigeenisiä proteiinirakenteita kutsutaan fimbrioiksi. ETEC-bakteerien pinnalta on löydetty useita erilaisia fimbriatyyppejä, mutta yleisin Suomessa vieroitusripulia aiheuttavista ETEC kannoissa tavattava fimbriatyyppi on F4 (Bertschinger ja Fairbrother 1999). F4-fimbria muodostuu sadoista yhteenketjuttuneista FaeG-alayksikköproteiineista. F4-fimbrian sekä adhesiivisten että antigeenisten ominaisuuksien on todettu johtuvan FaeG-proteiinin rakenteesta (Bakker 1992, Van den Broek ym. 2000).

Ripuli aiheuttaa paitsi turhaa kärsimystä porsaille, myös tuotannon heikkenemistä kasvun hidastuessa ja ääritapauksissa porsaskuolemia. Hygienian ja kasvatusolosuhteiden korkea taso ovat ensisijaisen tärkeitä pyrittäessä ehkäisemään ripulisairauksien puhkeaminen, mutta usein joudutaan myös turvautumaan antibiootteihin ja yksittäisten eläinten rokottamiseen. Lisäksi tavanomainen rokottaminen ripulisairauksia vastaan on melko tehotonta, koska se aktivoi limakalvovälitteisen vastaainetuotannon sijasta lähinnä verenkiertojärjestelmän vasta-ainetuotannon (Van den Broek ym. 2000).

Kun porsaat immunisoidaan oraalisesti puhdistetulla F4-fimbrialla, aktivoituu myös limakalvovälitteinen immuunijärjestelmä. Suoleen erittyvät IgA vasta-aineet sitoutuvat F4 ETEC-bakteerien pintarakenteisiin ja estävät kiinnittymisen ohutsuolen limakalvon reseptoreihin ehkäisten näin ripulin puhkeamisen (Van den Broek ym. 1999 b,c).

Tämän projektin tarkoituksena on kehittää uusi tapa porsasripulin ehkäisemiseksi. Ideana on kehittää FaeG-proteiinia tuottavia siirtogeenisiä viljelykasveja, joista valmistettua rehua voidaan suoraan käyttää 'syötävänä rokotteena'.

Tässä tutkimuksessa testattiin kasvissa tuotetun F4-fimbrian pääalayksikköproteiinin (FaeG) kestävyyttä porsaiden ruuansulatuskanavaa simuloivissa proteolyyttisissä olosuhteissa. Kasvissa tuotettu FaeG-proteiini kesti 120 minuuttia ankarissa maha- ja suolinesteolosuhteissa. Työssä tutkittiin myös FaeG-proteiinin adhesiivisiä ominaisuuksia. Tulokset osoittivat, että kasvissa tuotettu FaeGproteiini pystyy kiinnittymään porsaiden ohutsuolesta eristettyjen nukkalisäkkeiden harjareunuksessa esiintyviin F4-reseptoreihin ja samalla ehkäisemään F4 ETEC-bakteerien kiinnittymistä suoliepiteeliin.

\section{Aineisto ja menetelmät}

FaeG-proteiinin tuottajina tässä tutkimuksessa käytettiin agrobakteerilla transformoituja tupakkakasveja (helposti transformoituva mallikasvi). Lehtimateriaali homogenoitiin mekaanisesti puskuriliuoksessa (200mM Hepes-KOH, pH 7.0, 10mM DTT).

Kasvissa tuotetun alayksikköproteiinin kestävyyttä porsaiden ruoansulatusolosuhteissa tutkittiin kasviuutteelle suoritetuilla in vitro maha- ja suolinestesimulaatioilla. Simulaatiotestit tehtiin soveltaen Astwoodin ym. 1996 ja Fuchsin ym. 1993 käyttämiä in vitro-testimenetelmiä. Maha (pepsiini)- ja 
suolisimulaationesteet (pankreatiini) valmistettiin ohjeen (The United States of Pharmacopeia, 1990) mukaan ja olosuhteet säädettiin vastaamaan porsaiden ruoansulatusolosuhteita (Snoeck ym. 2003). Simulaationesteiden aktiivisuus testattiin ennen varsinaisia simulaatioita erillisillä testimenetelmillä (Ryle 1984, Twining 1984). Simulaationestettä ja kasviuutetta sekoitettiin keskenään yhtä suuret tilavuudet. Simulaatioista otettiin aikapistenäytteet $0,10,30,60,90$ ja 120 minuutin kohdalla. Aikapistenäytteet eroteltiin 10\% SDS-page geeleissä ja proteiinit siirrettiin geeleiltä nitroselluloosakalvoille vasta-ainedetektiota varten. Vasta-ainedetektio tehtiin FaeG-proteiinia vastaan tuotetulla kanin antiseerumilla. Aikapistenäytteiden kokonaisproteiinit määritettiin samoista näytteistä Coomassievärjäyksellä.

Adheesiotestausta varten FaeG-proteiini eristettiin kasviuutteesta seuraavasti. Kasviuute sentrifugoitiin ja liukoinen kasviproteiinifraktio altistettiin viideksi minuutiksi pepsiinidigestiolle mahasimulaationesteessä, jolloin suurin osa kasviproteiineista hajosi. FaeG-proteiini puhdistettiin jäljelle jääneestä liuoksesta anioninvaihtokromatografian ja $2.5 \mathrm{M}$ ammoniumsulfaattisaostuksen avulla. Adheesiotestaus tehtiin Van den Broekin ym. 1999a mukaan. Lyhyesti, porsaiden (2kpl) suolista eristetyt

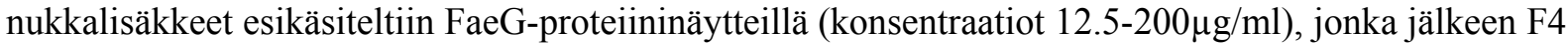
ETEC-bakteerit lisättiin liuokseen. Enterosyyttien harjareunukseen kiinnittyvien F4 ETEC-bakteerien lukumäärä laskettiin kustakin näytteestä 40 kohdasta $50 \mu \mathrm{m}$ matkalta ja keskiarvona määritettiin eri FaeG konsentraatioden kyky ehkäistä F4 ETEC-bakteerien sitoutumista harjareunukseen. Adheesiotestin spesifisyys varmistettiin Van den Broekin ym. 1999a mukaan.

\section{Tulokset ja tulosten tarkastelu}

Tuottaakseen hyvän limakalvovälitteisen immunologisen vasteen antigeenisten proteiinien tulee kestää ruoansulatuselimistön vahvat proteolyyttiset ja happamat olosuhteet muuttumattomina. Porsaiden ruoansulatusolosuhteita jäljittelevät maha- ja suolinestesimulaatiot osoittivat kasvissa tuotetun FaeG- proteiinin kestävän ruoansulatuskanavan ankarissa proteolyyttisissä olosuhteissa vähintään kaksi tuntia. Porsaan mahanestettä simuloivissa olosuhteissa suurin osa kasviproteiineista hajotettiin nopeasti muutamassa minuutissa. Tämä osoittaa, että testissä käytetyt proteolyyttiset olosuhteet olivat hyvin ankarat. Myös suolinestettä simuloivissa olosuhteissa monet kasviproteiinit pilkkoutuvat ja osoittavat testin proteolyyttisyyden. Molempien testimenetelmien toimivuus varmistettiin myös erillisellä testimenetelmällä.

Saadakseen aikaan paikallisen limakalvovälitteisen immuunivasteen FaeG-proteiinin on pystyttävä tarttumaan porsaiden nukkalisäkkeiden reseptoreihin. Suolessa vapaana oleva fimbrian alayksikköproteiini kilpailee myös suoraan F4 ETEC-bakteerien kanssa reseptoripaikoista ja näin ehkäisee F4 ETEC-bakteerien reseptoreihin kiinnittymistä (antikolonisaatio). Porsaiden nukkalisäkkeillä suoritettu adheesiotesti osoitti, että kasvista eristetty FaeG-proteiini pystyy tarttumaan harjareunusten reseptoreihin ja samalla ehkäisemään F4 ETEC-bakteerien kiinnittymistä. FaeG-proteiinin kyky ehkäistä F4 ETEC sitoutumista osoittautui myös konsentraatioriippuvaiseksi. 34-71\% F4 ETEC bakteerien sitoutumisesta pystyttiin ehkäisemään, kun nukkalisäkkeet käsiteltiin $12.5-200 \mu \mathrm{g} / \mathrm{ml} \mathrm{FaeG} \mathrm{proteiinilla}$ ennen F4 ETEC-bakteerien lisäämistä. Kasvissa tuotetun FaeG-proteiinin inhibiitiokyky osoittiin myös spesifiseksi, koska testissä käytettyjen FaeG-näytteiden esikäsittely F4-spesifisellä vasta-aineella teki nukkalisäkkeet jälleen alttiiksi F4 ETEC bakteerien sitoutumiselle.

Edellä esitettyjen tulosten ansiosta on todennäköistä, että kasvissa tuotettu FaeG-proteiini läpäisee porsaiden mahalaukun, pystyy kiinnittymään porsaiden ohutsuolen nukkalisäkkeiden harjareunuksessa esiintyviin F4-reseptoreihin ja näin todennäköisesti myös käynnistämään ripulilta suojaavien IgA-molekyylien tuoton ja erityksen ohutsuoleen.

Olemme mallikasvina käytetyn tupakan lisäksi tuottaneet siirtogeenisiä ohralinjoja, joissa FaeG-proteiinia tuotetaan jyvän endospermissä, sekä sinimailaslinjoja, joissa alayksikköproteiinia tuotetaan kaikissa kasvisolukoissa. Koska suun kautta annetun bakteeriperäisen F4-fimbrian on jo aiemmin todettu estävän F4 ETEC-bakteerien kiinnittymistä ohutsuoleen ja aktivoivan limakalvovälitteisen immuunivasteen ripulia aiheuttavia F4 ETEC-bakteereita vastaan (Van den Broeck ym. 1999 b,c), seuraava askel projektissamme onkin testata, aiheuttaako myös rehukasveissa tuotettu F4-fimbrian alayksikköproteiini suojaavan immuunivasteen synnyn porsailla suun kautta annettuna. Vieroitusripulin ehkäisemisen lisäksi projektimme tutkimustuloksia voidaan tulevaisuudessa hyödyntää laajemminkin kehiteltäessä uusia kasviperäisiä tuotteita niin ihmisten kuin kotieläintenkin rokottamiseen. 


\section{Kirjallisuus}

Astwood, J. D., Leach J. N. and Fuchs R. L. 1996. Stability of food allergens to digestion in vitro. Nat Biotech 13:1269-1273.

Bakker D., Willemsen P.T.J., Simons L.H., van Zijderveld F.G. and de Graaf F.K. 1992. Characterization of the antigenic and adhesive properties of FaeG, the major subunit of K88 fimbriae. Mol Microbiol 6: 247-255 Bertschinger H.U. and Fairbrother J.M. 1999. Escherichia coli infections. In B.E. Straw, S. D'Allaire, W.L. Mengeling and D.J. Taylor, (eds), Diseases of Swine, Ed 8. Iowa State University Press, Iowa, pp 431-454 Cowart R.P. 1995. An Outline of Swine Diseases: a Handbook, pp 54-56

Fuchs R.L., Ream J.E., Hammond B.G., Naylor M.W., Leimgruber R.M. and Berberich S.A. 1993. Safety assessment of the neomycin phosphotransferase II (NPTII) protein. Bio/Technology 11: 1543-1547

Ryle, A. P. 1984. Pepsins, gastricsins and their zymogens, pp. 228-233 in Methods of Enzymatic Analysis. Bergmeyer, H. U. (ed.) Verlag Chemie, Deerfield Beach, FL.

Snoeck V., Cox E., Verdonck F., Joensuu J.J. and Goddeeris B.M. 2003. Influence of pH and gastric digestion on antigenicity of F4 fimbriae for oral immunization. Veterinary Microbiology, in press

Twining S.S. 1984. Fluorescein isothiocyanate-labeled casein assay for proteolytic enzymes. Anal Biochem 143:30-34

The United States of Pharmacopeia. 1990. Vol. XXII, p. 1788-1789. United States Pharmacopeial Convention, Inc, Rockville, MD.

Van den Broeck W.V., Cox E. and Goddeeris B.M. 1999a. Receptor-specific binding of purified F4 to isolated villi. Vet Microbiol 68: 255-263

Van den Broeck W.V., Cox E. and Goddeeris B.M. 1999b. Induction of immune responses in pigs following oral administration of purified F4 fimbriae. Vaccine 17: 2020-2029

Van den Broeck W.V., Cox E. and Goddeeris B.M. 1999c. Receptor-dependent immune responses in pigs after oral immunization with F4 fimbriae. Infect Immun 2: 520-526

Van den Broeck W.V., Cox E., Oudega B. and Goddeeris B.M. 2000. The F4 fimbrial antigen of Escherichia coli and its receptors. Vet Microbiol 71: 223-244 